\title{
The Dairy Price Support Program: A Study of Misdirected Economic Incentives
}

\author{
Michael T. Belongia
}

\begin{abstract}
$\mathbf{T}$
HE dairy price support program is likely to be the focal point of agricultural policy in 1984. Dramatic increases in the program's cost have made it a visible target for politicians concerned about federal budget deficits. Consumer groups, who favor lower dairy prices, also are opposed to the current program. Livestock producers, however, opposed recent changes in the dairy program, fearing that such efforts to reduce surplus dairy production will promote a significant slaughter of dairy cows that will keep beef prices at low levels. These groups and their opposition to the dairy program were confronted, as usual, by a politically powerful dairy lobby. ${ }^{1}$
\end{abstract}

This article first reviews the history and mechanics of the dairy price support program. Elementary economic principles show why the dairy program has generated an increasing volume of dairy surplus by effectively maintaining milk prices above the competitive market level. The program's guarantee to purchase all surplus product at the support price is shown to produce an inefficient allocation of resources and a transfer of wealth to dairy producers and suppliers of production inputs. The analysis also demonstrates

Michael T. Belongia is an economist with the Federal Reserve Bank of St. Louis. Robert W. Hess provided research assistance.

'Since January 1,1981 , the dairy lobby has contributed over $\$ 1.3$ million to 293 members of the House of Representatives. Two-thirds of these officials voted against reductions in dairy price supports. Moreover, much of legislative support for the dairy program - which raises the cost of dairy products to consumers - comes from congressmen who, for all practical purposes, have no dairy farmers in their districts. For example, in the 1982 election, the dairy lobby contributed to 117 congressmen from districts with less than 1 percent of their populations engaged in farming. Seventy-two of these congressmen voted against reductions in price supports. See Jackson and Birnbaum (1983). why a lower support price would reduce both surplus production and the prices of dairy products without large increases in the program's cost. The article's final section evaluates the likely effects of the compromise dairy legislation, passed by Congress and signed by the President last November, that provides for direct payments to farmers for reducing output.?

\section{THE DAIRY PROGRAM: A BRIEF HISTORY}

For many years, milk prices have been supported, both directly and indirectly, by a variety of government initiatives. ${ }^{3}$ In 1922, the Capper-Volstead Act effectively exempted dairy cooperatives from antitrust actions, thereby allowing producer organizations to restrict output, charge higher prices for milk and earn monopoly profits. Later, in 1935, amendments to the Agricultural Adjustment Act established marketing orders that set minimum prices for milk; the USDA was charged with enforcing the payment of established minimum prices to farmers.

Since 1949 , the federal government has supported the price of milk directly by guaranteeing to purchase all milk that cannot be sold in the market at the federally established support price $\$ \$ 12.60$ per hundredweight (cwt.) currently; $\$ 13.10$ prior to last November). The price of milk is maintained by Commodity Credit Corporation (CCC) purchases of manufactured dairy products from dairy processors. The $\mathrm{CCC}$ actually

\footnotetext{
${ }^{2}$ For general details on provisions of the legistation, see King ( $1983 a$ ).

The dairy program is discussed in detail in Manchester (1983). Donahue (1983) and Malcolm (1983) provide brief surveys of the dairy program and its history.
} 
Chart

CCC Purchase of Dairy Products: Butter, Cheese and Dry Milk

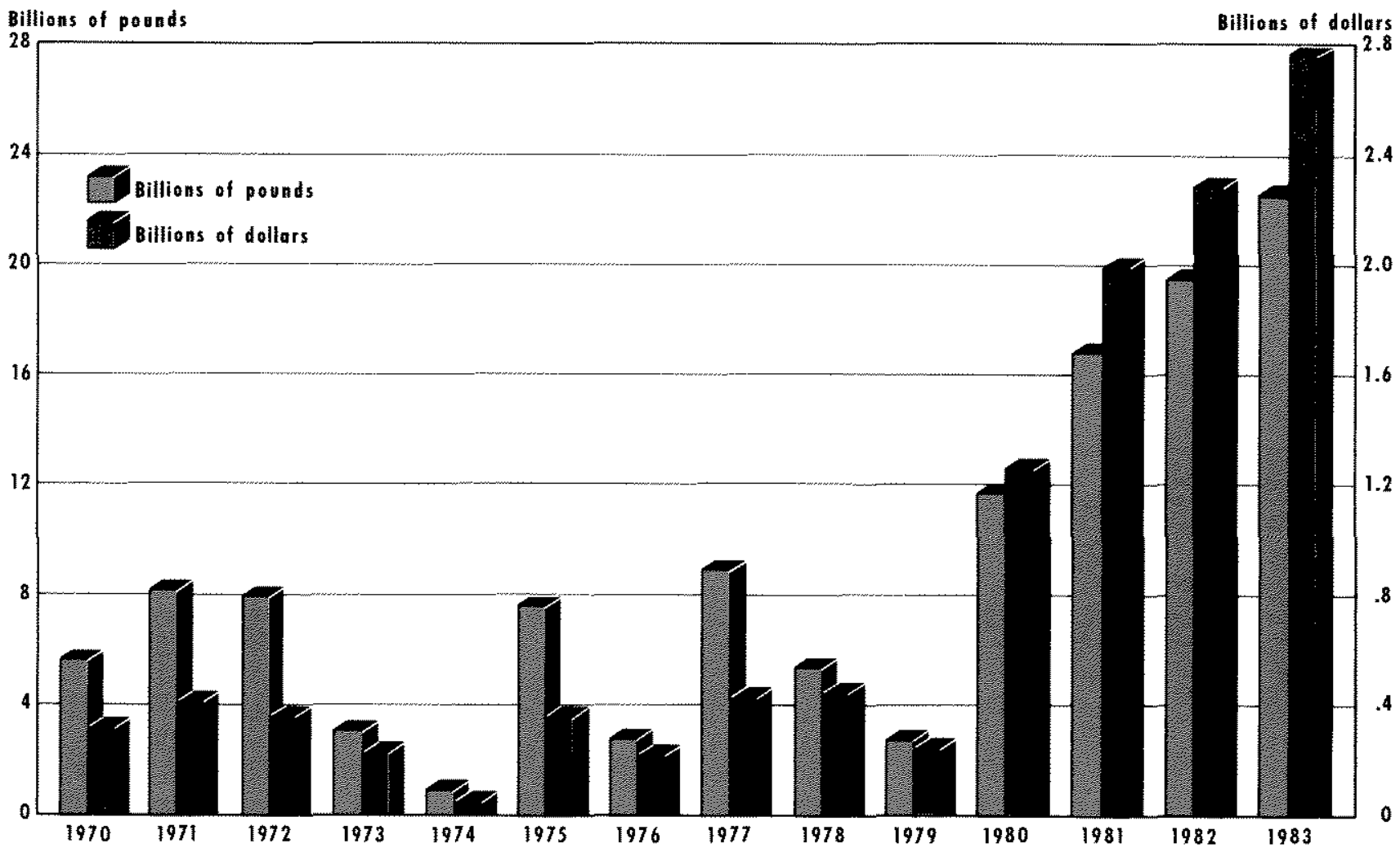

II Data for fiscal year 1983 are preliminaty

processed milk products: butter, cheese and nonfat dry milk. Prices also are supported indirectly by food stamps, import restrictions on foreign dairy products, and government purchases of milk for use in the National School Lunch Program. To support milk prices at the pre-November level, the CCC has purchased more than 10 percent of all milk marketed by farmers in recent years.

At the previous support price of $\$ 13.10$ per cwt., the volume of CCC purchases of surplus dairy product grew rapidly since $1979 .{ }^{4}$ In the fiscal years $1977-79$, net CCC expenditures on the dairy program averaged less than $\$ 500$ million annually. ${ }^{5}$ As the data in chart 1

\footnotetext{
${ }^{4}$ Previous legislation had mandated an adjustment in the support level each April and October such that the new support price represented 80 percent of parity. The last such increase, which raised the support level to $\$ 13.10$ /owt., occurred in April 1981 .

${ }^{5} T$ This average expenditure, however, includes only direct government outlays for the purchase and storage of surplus product. Several
}

indicate, this expenditure more than tripled to an average cost of more than $\$ 1.8$ billion for fiscal years 1980 82. In the fiscal year ending September 30,1983 , CCC outlays for the purchase and storage of surplus dairy product exceeded $\$ 2.7$ billion. ${ }^{6}$ These rapid increases

studies have attempted to measure the additional social loss associated with the higher prices paid by consumers for the smaller volume of dairy products they consume. Although these studies are somewhat dated, the indirect social cost of the dairy price support program in the early 1970 s was estimated to average nearly an additional $\$ 100$ million per year. In other words, the direct cost of the dairy program represented, on average, about halt of its full social cost. Since large increases in the volume of surplus product purchased in recent years implies that the gap between the support price and competitive market price has widened substantially, the indirect social cost of the program may now be considerably larger. See Heien (1977), 1ppolito and Masson (1978), and Dahlgran (1980) for details on the derivation of the social cost estimates.

${ }^{6}$ The United States is not alone in trying to curb large increases in the costs of price support programs. See Tangermann (1983), for exam. ple, on the structure and cost of the European Economic Community's dairy price support program. 
Chart 2

Trends in Milk Production

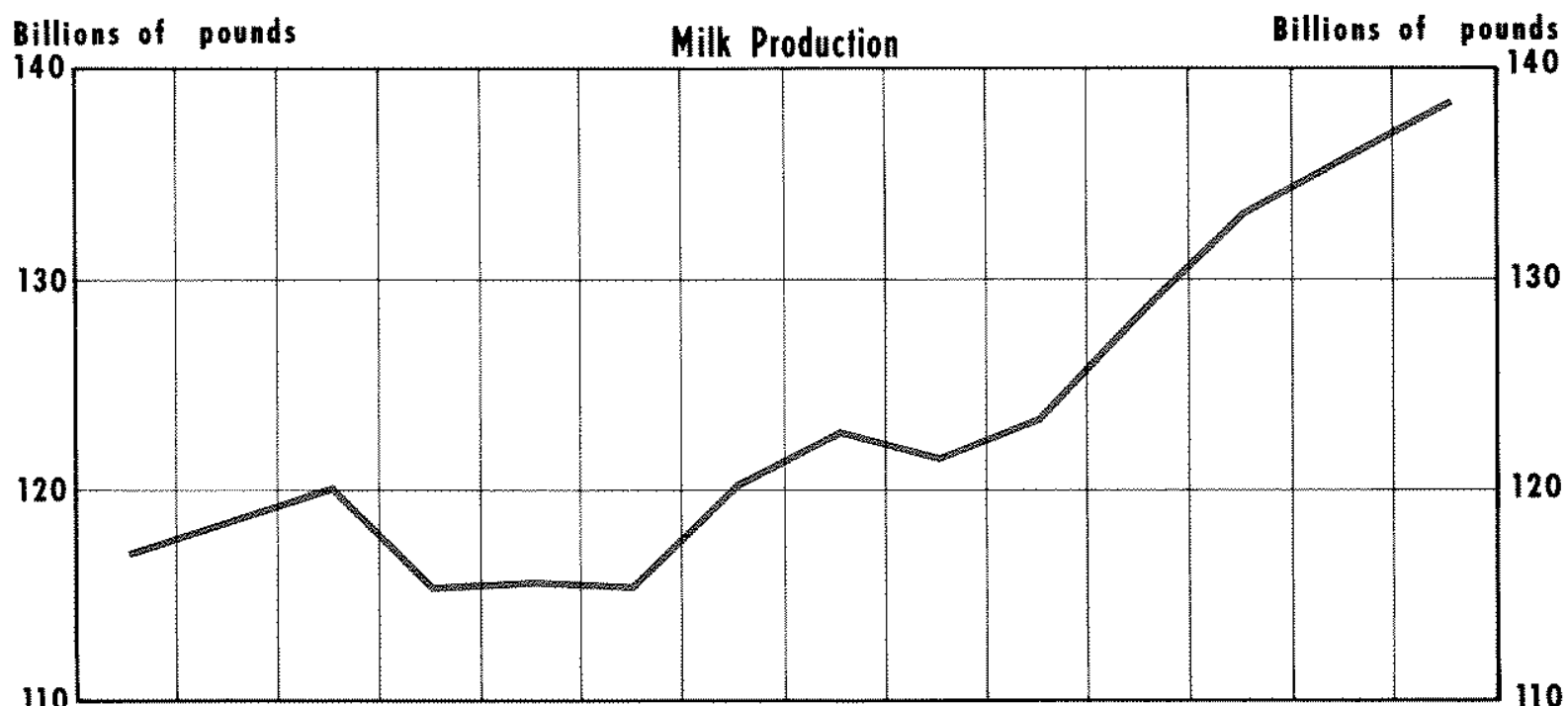

Thousands of pounds

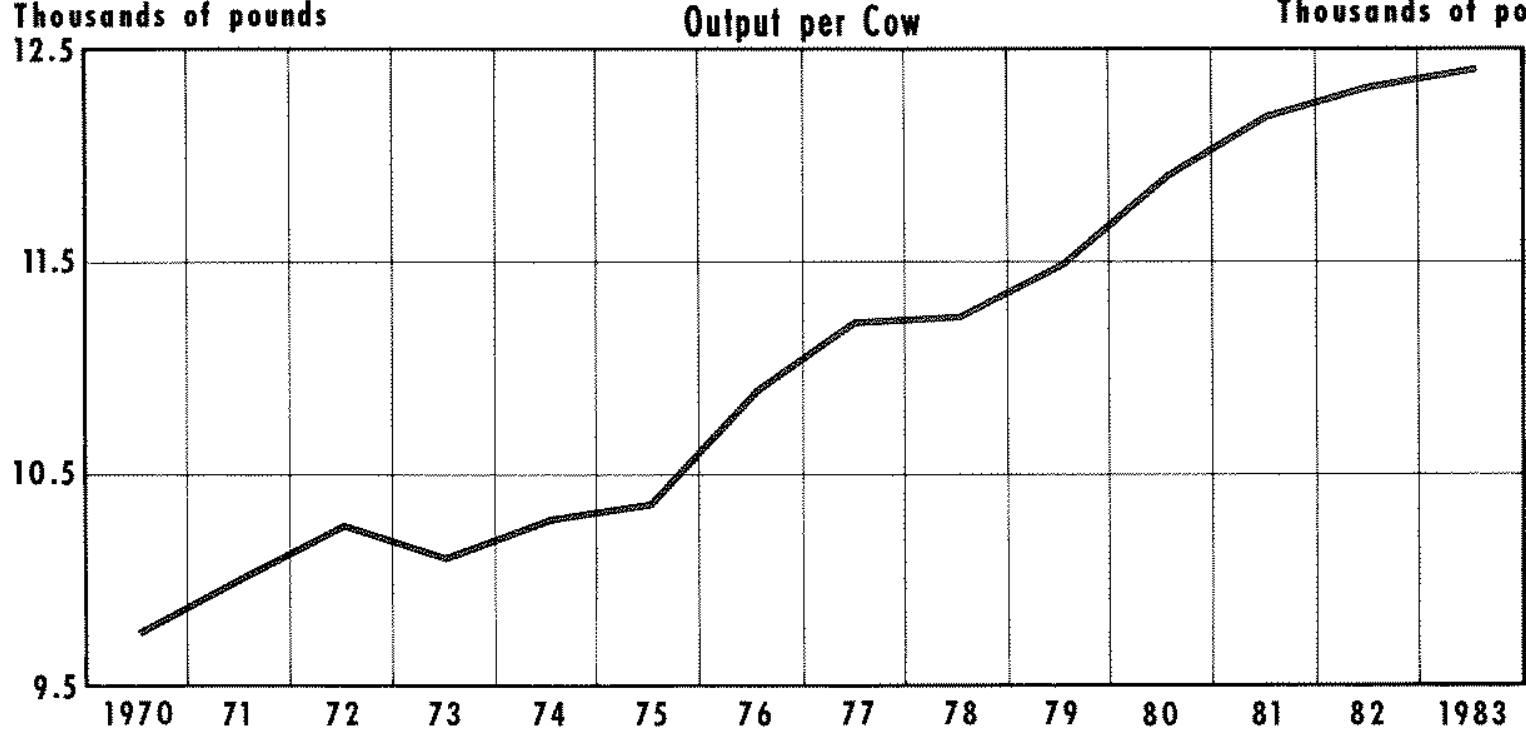

Thousands of pounds

11.5

occurred, in part because the dairy program - unlike the price support progeams of other commodities places virtually no restrictions on the volume of milk that a dairy farmer can market at the support price.

The cost of the program increased, of course, because the program's incentives caused output to grow at a faster rate than the demand for dairy products. As the data plotted in chart 2 indicate, milk production increased at a 1.3 percent annual rate since 1970 . Aside from the incentive effects of the dairy program, this steady increase in output also is partially attributable to the 1.9 annual increase in average output per dairy cow. Most important to the present analysis, however, is the much larger 2.7 percent average rate of increase in milk production since 1978. 


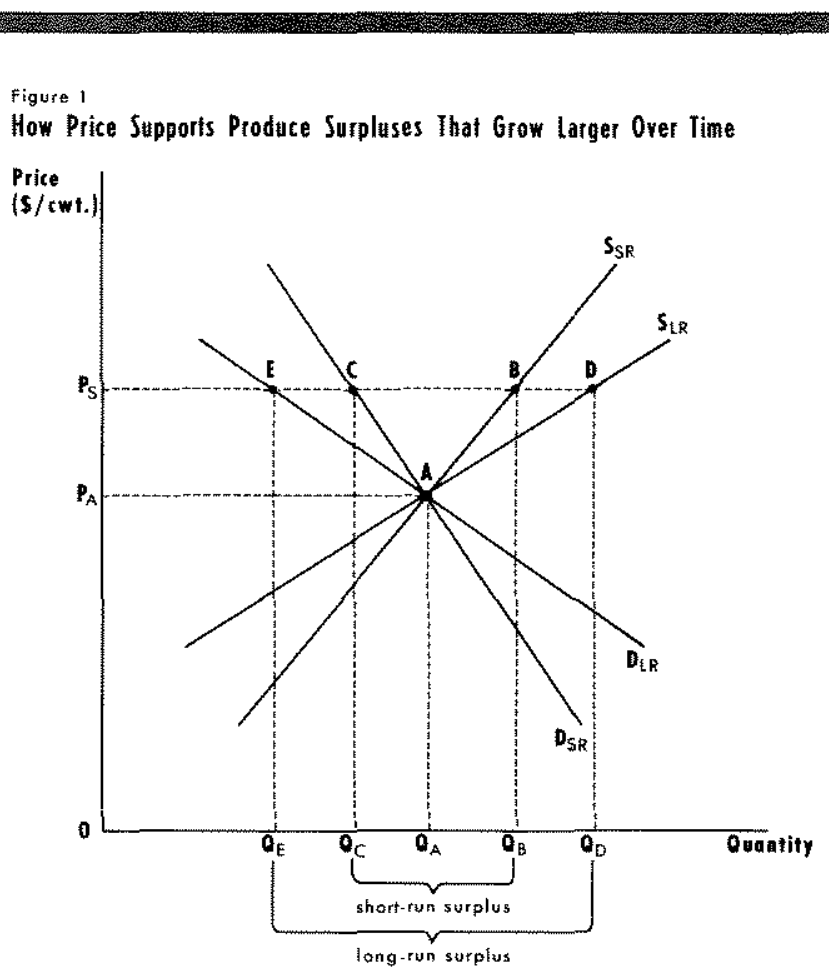

The most recent version of the dairy program prior to the adoption of the paid diversion plan last November - supported the price of milk at $\$ 13.10$ per cwt, but imposed two 50-cent-per-cwt. fees. The first 50-cent fee was collected on all milk marketed, effectively lowering the 1983 support price to about $\$ 12.60$ per cwt. The second 50-cent fee was to be collected only if CCC purchases of surplus product were expected to exceed 7.5 billion pounds (milk equivalent); this second fee was to be refunded, however, to producers who reduced their production to specified levels. Since this program was not in effect long enough for the second assessment to be binding, the analyses that follow deal in terms of only one 50 -cent deduction.

\section{"TME SIMPLE ECONOMICS OF DAIRV PRICE SUPRORTS}

To illustrate how the existence of a price support program affects the dairy market, consider the model of the dairy market shown in figure 1. Without a support price, the long run market equilibrium for milk would be at point $A$ where, at the competitive price $P_{A}$, the quantity of milk supplied to the market by milk producers $\left(\mathrm{Q}_{A}\right)$ is equal to the quantity demanded by consumers $\left(Q_{A}\right)$. At $P_{A}$, where the market supply and demand schedules intersect, there is neither a surplus nor a shortage of milk. Since the quantity of milk
Figure 2

How Price Suppots Encourage Hote Prodaction and More Producers

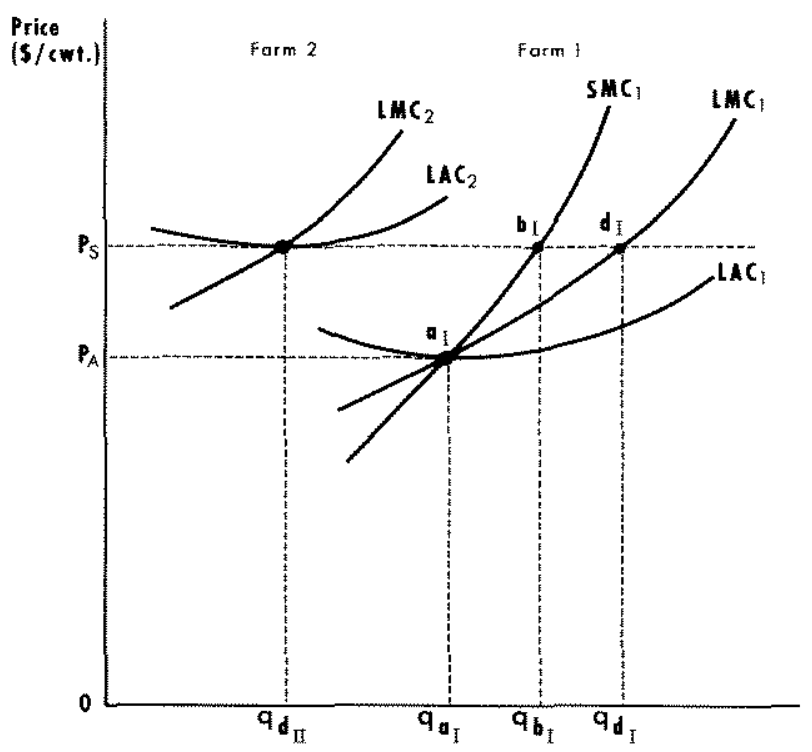

brought to the market by producers at that price exactly satisfies consumer demand, there are no incentives for either producers or consumers to change their rates of production or consumption.

If the support price is above $\mathbf{P}_{\mathrm{A}}$, both consumers and producers will modify their behavior in predictable fashion. A price support like that represented by $P_{S}$ guarantees producers a higher return for their output than they would otherwise have obtained. In the short run, this higher return will provide an incentive for dairy farmers to increase output to point $B$. At the higher market prices, however, consumers will reduce their milk consumption until they reach point $C$. The net result of the increased production and reduced consumption produces a short-run milk surplus, in this instance equal to the difference between the quantities supplied and demanded at $P_{S}\left(Q_{B}-Q_{C}\right)$.

\section{SHORT-ITUN AND LONG-RUN CONSEQUENCES OF MILK PRICE SUPPORTS}

Figure 2 shows why these changes in the dairy market occur by focusing on the revenue and cost curves of a representative dairy farmer. In the absence of a support price for milk, the representative producer (Farm I) would produce $q_{a}$ units of milk at the competitive price of $P_{A}$. At this level of output, both his short-run 
and long-run marginal costs (SMC and LMC) of increasing output by one unit are exactly equal to the price he would receive from selling one more unit. He has no incentive to increase milk production beyond $\mathrm{q}_{\mathrm{a} \text {. }}$ however, because the marginal cost of doing so exceeds $P_{A}$, the price he would receive for the milk. Increasing output beyond $\mathrm{q}_{\mathrm{a}}$, then, would produce a loss equal to the vertical distance between average cost (SAC) and price times the total amount produced.

The stability of the representative producer's equilibrium at $a_{1}$ is reflected in the market equilibrium at point $A$ in figure 1 , where $Q_{A}$ units would be produced and consumed at the price $P_{A}$. Output levels $Q_{A}$ (for the industry) and $q_{a I}$ for dairy Farm I depict a long-run equilibrium for several reasons. First, because the price received by each producer for his milk is equal to both his marginal and average costs of production, the representative producer is earning only a normal rate of return on his production. ${ }^{7}$ The absence of short-run losses or rents indicates that there are no incentives to attract new producers to the industry (e.g., Farm II) or induce existing producers to change their rates of output.

The figure also indicates that the total output produced by all dairy farmers is sold in the market for the price at which the markef supply and demand schedules intersect. Until some exogenous factor changes either the price or the position of the curves depicted in figure 1, the representative producer's output and the market price and quantity will remain at their respective long-run equilibrium points.

The introduction of a price support increases the price received by producers and upsets the long-run equilibrium at point $A$ in figure 1 . In the short run, farmers engaged in milk production respond by increasing their rates of output until their SMC is equal to the new higher marginal revenue (which is equal to the. support price, $P_{S}$. Thus, Farm I increases its rate of output to $b_{1}$ units, which, when added to the increased production of all other current dairy farmers, increases the quantity supplied in the market to $\mathrm{Q}_{\mathrm{B}}$ (figure 1). At the higher support price, however, consumers pur" chase only $\mathrm{Q}_{C}$ units of milk. In the short run, the price support generates a market surplus equal to the difference between quantities supplied and demanded at the support price $\left(\mathrm{Q}_{\mathrm{B}}-\mathrm{Q}_{\mathrm{c}}\right)$.

\footnotetext{
Included in these costs is the capitalized value of the net eamings of the dairy farm; this represents the sale value of the farm and, hence, is a "cost" of staying in the dairy business to the current farmer. See, for example, Stigler (1966).
}

This initial surplus, however, understates the longrun impact of the price support program. The surplus will continue to increase because the maintenance of a support price above average cost introduces short-run economic rent equal to the difference between the support price and average cost times the higher level of output produced. This rent gives an incentive to new producers to enter the industry (e.g., Farm II) and to existing producers to increase permanently the size of their capital stock (larger herds, larger barns, etc.).

As new farms begin and existing farms expand production, there will be increased demand for the scarce resources needed to produce milk: dairy cows, feed, equipment, land and the specific skills necessary to be a successful dairy farmer. Increased demand for these inputs eventually will raise the marginal and average costs of producing milk to $\mathrm{LMC}_{1}$ and $\mathrm{LAC}_{1}{ }_{1}$ in figure 2 where, at the new long-run equilibrium position $\left(q_{d I}\right.$ and $\mathrm{q}_{\mathrm{du}}$, economic profits for each producer in the industry equal zero, just as they did originally. Notice in figure 1, however, that the higher support price at $P_{S}$ eventually produces a long-run surplus of dairy products equal to the difference $\mathrm{Q}_{\mathrm{D}}-\mathrm{Q}_{\mathrm{E}}$. The surplus is larger in the long-run because supply and demand schedules become more elastic over time. ${ }^{8}$

\section{BENEFICIARIES OF THE DAIRY PROGRAM}

Who, then, benefits from the dairy program and who lobbies for its continuation? First, farmers who own dairy operations have benefited from price supports because the values of the specific inputs including their own specific knowledgel used to produce milk have increased. Without a support program, dairy farming would be less profitable and, consequently, the land, equipment and dairy cows used in milk production would be less valuable.

The suppliers of inputs used in the dairy industry also have benefited from the price support program. The increased demand for their inputs by both old and new dairy farmers tends to raise input prices and permits suppliers of these inputs to earn greater profits

\footnotetext{
${ }^{8}$ The absolute value of the slope of a supply or demand schedule is smaller as it becomes more elastic. Demand is more elastic in the long run because substitutes can be found for higher priced dairy products. The longmrun supply curve is more elastic than the shortrun supply schedule because of the eniry of new producers to the industry. It is easy to see, for any level of price supports, that flatter suppty and demand curves will increase quantity supplied, reduce quantity demanded and increase the size of the market surplus.
} 
than they would in the absence of a price support program. Thus, not surprisingly, both input suppliers and dairy farmers oppose large reductions in the program's benefits because such reductions would reduce their wealth.

\section{MMPACT OF THE 50-CENT DEDUCTIONS IMPOSED IN 1983}

An attempt was made in 1983 to reduce the growing volume of surplus production - caused by behavioral relationships like those in figures 1 and 2 - with the imposition of a 50 -cent fee on all milk produced. Although adopted early in 1983, court rulings delayed the actual collection of fees until late in the year. Essenfially, the fee amounted to a reduction in the support price.

In terms of figure 3 , the 50-cent deduction can be treated as a parallel downward shift in the support price line from $\$ 13.10$ to $\$ 12.60$ per cwt. From basic economics, we know that a decrease in output price will, ceteris paribus, lead to a decrease in output; producers move down and to the left along their upwardsloping marginal cost curves. Starting from an assumed long-run equilibrium at point $A_{p}$ the 50-cent deduction would be expected to move producers toward point $B_{p}$ as they attempt to equate marginal cost with the new, lower level of marginal revenue (price). The net effect of all producers decreasing output in this manner would be a reduction in quantity supplied to the market, similar to the movement from point $B$ to point $A$ in figure 1. In short, an effective decrease in prices will cause individual producers and, hence, the industry to scale back production to the point where the new support price is equal to marginal cost.

A second effect of a lower support price - through its negative effect on production - would be a reduction in the demand for inputs used in the dairy industry. The reduced input demand would tend to reduce input prices and exert pressure on some inputs to leave dairy production. This market reaction would lower costs and ultimately shift LAC to $L A C^{\prime}$ as figure 3 shows. In fact, producers would continue to exit from the dairy industry until $\mathrm{LAC}^{\prime}=\mathrm{SMC}^{\prime}=\$ 12.60$ for all existing farmers and a new long run equilibrium exists at point $B_{p}$.

Thus, the 50-cent deduction should have promoted a decrease in milk production. The absence of production controls, however, led to the speculation among some analysts that farmers would compensate for the 50-cent deductions by producing more milk even if it meant producing at a loss. ${ }^{9}$ The argument supporting this conclusion is that farmers need to generate a minimum level of revenue - or cash-flow - to meet operating expenses. Therefore, if prices are reduced, sufficient cash-flow can be generated only by increasing output. Thus, the argument goes, the deduction plan would cause an increase in the dairy surplus rather than a curtaiment in its growth.

This reasoning is specious, however, as can be seen from figure 3 . If the representative producer's SMC curve is upward sloping, a lower price will be associated with a reduced volume of output as producers move down and to the left along the SMC curve. Therefore, unless the costs facing dairy producers behave contrary to usual relationships, a lower support price should cause reductions in output. ${ }^{10}$ The gaps between the predictions of economic theory and producers' actual response to the 50-cent deductions suggest an alternative explanation for the increase in milk production in 1983.

\section{An Alternative Explanation for Increased Output Under Fee Assessment}

A more conventional explanation of the increased dairy production in 1983 can be based on a different view of the cost structure facing milk producers. In stead of showing farmers producing at a short-run loss after the 50-cent deduction as in figure 3 , available data indicate that the effective support price, even with the deduction, still was greater than LAC. Under these conditions, new and existing producers could continue to earn short-run economic rents by increasing output as they did last year.

The best evidence that a $\$ 12.60 /$ cwt. support level remained above average cost can be found in data on the size of dairy herds. Despite the 50-cent deduction

\footnotetext{
In recent congressional debate over changes in dairy legislation, comments like the following were common: "Instead of helping to lower the milk supply, the $\$ 1$ assessment program . . has forced too many dairy farmers to increase production in order to keep their cash flow from declining to stay in business." See Albosta (1983),

${ }^{10}$ Aside from the downward-sloping marginal cost argument, one other explanation could explain increased production in response to a lower support price. If the labor of the farm owner is treated explicitly as an input and the owner faces a tradeoff between extra revenue and leisure in his use of free time, it is possible to construct a theoretical preference mapping that would allocate marginal time to the production of exira revenue from increased milk output.
} 


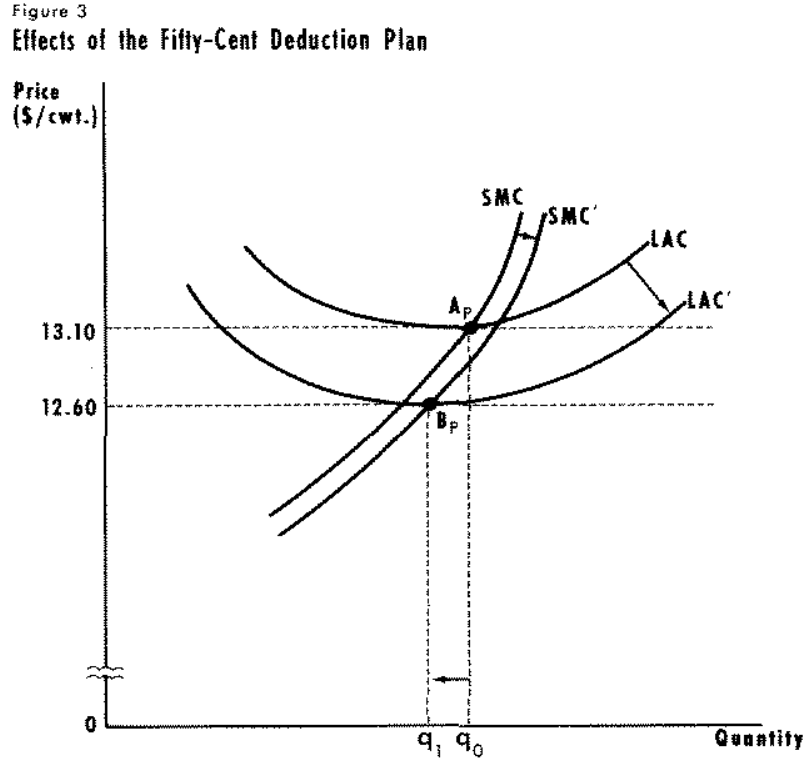

and higher feed costs, farmers increased the size of their herds during 1983. Moreover, with a record proportion of replacement heifers, famers are likely to expand herds even further in 1984. These data suggest that the LAC facing the typical producer still was less than the support price of $\$ 12.60$; consequently, farmers were finding it profitable to expand production. The data also imply that short-run rents could be earned by dairy producers until the entry of new firms and increased input demand increased the LAC to $\$ 12,60$.

The production decisions of dairy farmers in recent years appear to be consistent with the relationships shown in figure 4 . Historical data suggest that producers responded to higher support prices in 1980 by increasing production from, for example, $q_{a}$ to $q_{c}$ in figure 4. Furthermore, good weather and the incentives of the grain price support programs produced large stocks of relatively cheap feed grain. Lower feed prices would shift SMC and SAC downward to positions like $\mathrm{SMC}^{\prime}$ and $\mathrm{SAC}^{\prime}$ in figure 4. If these cost shifts have, in fact, occurred, a lower support price of $\$ 12.60$ still produces short-run economic rents for all dairy farmers operating at point $D_{p}$. This explanation suggests that reductions in the support price beyond those achieved by the 50-cent fee are necessary to reduce surplus production. The relationships in figure 4 also suggest that if the support price is not reduced further surplus production will continue to grow until com petition for inputs increases $\mathrm{SAC}^{\prime}$ to a level that passes through point $\mathrm{D}_{\mathrm{p}}$.

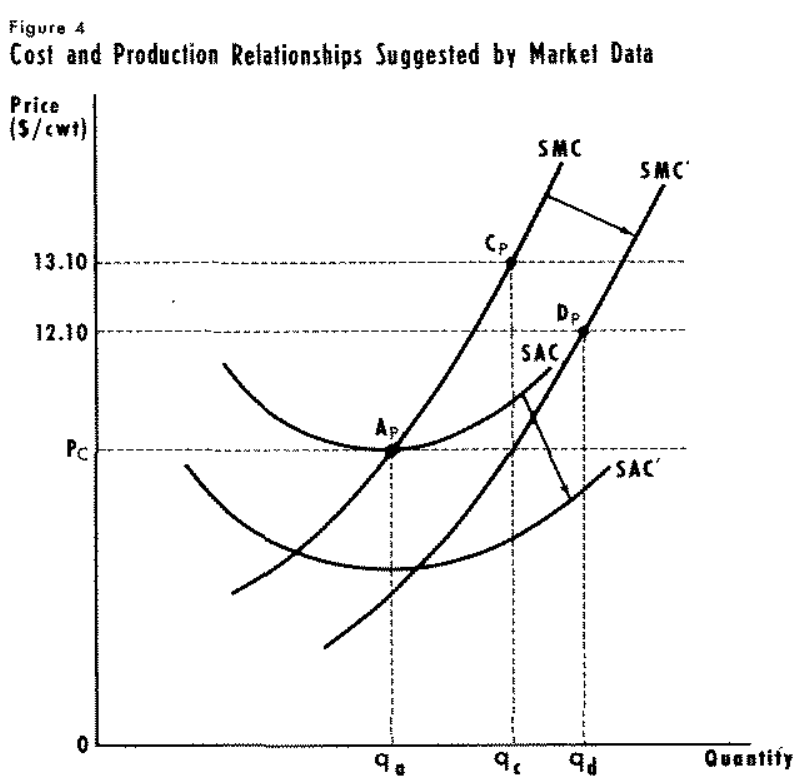

\section{POSSIBLE EFFECTS OF THE PAID DIVERSION PLAN}

Efforts to reduce the support price further to $\$ 11.60$ per cwt. have been defeated in Congress. Instead, compromise legislation that combines the 50 cent fee collection and a lower $\$ 12.60$ per cwt. support price (\$12.10 effective support level) with a plan to pay farm ers directly for reducing output has been passed; the payment is $\$ 10$ per cwt. to farmers who reduce output by up to 30 percent of historical levels. The program is scheduled to be in effect for 15 months beginning January 1, 1984. The bill also contains provisions for further adjustments in the support level - either up or down - in 1985 if the Secretary of Agriculture expects CCC purchases to be less or greater than 5 billion pounds milk equivalent. The analysis that follows considers whether this combination of a lower support price and paid diversion is likely to achieve the desired reductions in surplus dairy production and program costs. $^{11}$

The key elements in plans to pay farmers directly to reduce output are the 1981-82 base used in determining their historical production levels and the net benefits to reducing output. Several existing pieces of data are especially pertinent to this analysis. First, a USDA study has determined that, since this 1981-82 base period, 58 percent of dairy farmers have increased

\footnotetext{
${ }^{11}$ Much of this analysis is based on Tipton (1983).
} 
output, while 36 percent decreased output. ${ }^{12}$ These data imply that individual dairy farms have very different cost structures and that their responses to a diversion payment will vary substantially.

The main consideration is the calculation of net benefits to reducing output. A first approximation of this value is simplified below (all entries are in $\$ / \mathrm{cwt}$.):

$+\$ 10.00$ diversion payment

$+\$ 7.00$ variable cost saved by reducing output

-\$12.60 income lost from milk not sold

$=4.40$ net benefit of reducing output.

This calculation actually is made more complicated, however, by the unknown costs and benefits of laking resources out of production, then, in 15 months when the diversion program expires, adding them back into production. In other words, a correct assessment of net benefits must be based on a present value calculation that includes the full costs and benefits of participating in the diversion program. These other costs and benefts include - among many others - net revenues from cows slaughtered now, future replacement costs of new cows and the increased long-run efficiency of the herd if older cows are replaced by younger animals. It is not clear, a priori, that the net benefits of the diversion program - crudely estimated above at $\$ 4.40 / \mathrm{cwt}$ - still are positive when the present values of expected costs and benefits are taken into account. ${ }^{13}$

\section{Likely Response to Current Diversion Incentives}

The response of famers to the paid diversion might be best analyzed by considering how different groups of dairy farmers have altered their rates of output in recent years. Consider first dairy farmers who have decreased production since the 1982 base year. These farmers voluntarily have reduced output in response to their relatively higher operating costs. By participating in the diversion plan, they will receive payments for output reductions already achieved in 1983 or planned for 1984. Therefore, while these producers have a strong incentive to participate in the diversion plan, it is not clear whether these payments will reduce their

\footnotetext{
${ }^{12}$ The remaining 6 percent of farms were formed after 1982 and would not quality for the diversion program.

73 Just prior to publication of this article, the USDA announced that only 12 percent of U.S. dairy farmers agreed to participate in the diversion program. This low rate of participation is expected to reduce dairy production by no more than 6 percent, about one-half the production cutback sought by the legisiation. A significant cost factor cited by farmers who elected not to participate in the program was the deterioration of their breeding stock's genetic pool that would result from selling some cows to reduce production for just 15 months. See King (1984) and Shipp (1984).
}

production beyond the levels already achieved voluntarily in response to higher operating costs.

In contrast, consider those dairy producers with relatively lower operating costs who have increased output since 1982. To qualify for the diversion payments, these producers would have to reduce output not only below the level planned in 1984, but also below the increased level of 1983 . Moreover, because these producers can produce at lower cost, the diversion payments may not be sufficient to offset the lost revenues from output reductions. Therefore, the extent to which dairy famers who increased production since 1982 will participate in the diversion plan is unknown. Chart 3 shows the break-even points for participating in the diversion plan for farmers who have expanded by different amounts since 1981-82. These data indicate that participation will be less profitable if output has been increased substantially in recent years.

The diversion plan, then, appears to focus on the following issues: relatively efficient producers -nearly 60 percent of the total _ are less likely to participate in efforts to reduce output; 6 percent more are not eligible to participate in the program. Less efficient producers - about 35 percent of the total - already have reduced output below the 1982 levels to be used as the historical basis for payments. Therefore, these producers will be paid for output reductions already achieved. Finally, it is unclear that the program's benefits will offset the full costs of adjusting production for a plan scheduled to last only 15 months. The question remaining is whether the incentives to reduce output are sufficient to generate further reductions beyond those realized since 1982

\section{One Study's Results}

One analyst has investigated and produced estimates of the diversion program's likely effects in $19844^{14}$ Under certain assumptions about participation in the program by different classes of producer, the plan would show an intended reduction of 15 billion pounds of milk at a taxpayer cost of $\$ 1.5$ billion 15 billion pounds $\times \$ 10$ per cwt.). Because 5.5 billion pounds of this reduction are likely to have already occurred, however, the diversion plan will pay $\$ 1.5$ billion for the $9.5(15.0-5.5)$ billion pound reduction in output attributable to the program itself.

This reduction in output would be offset somewhat, however, by the continuing increase in production by the more efficient producers. After estimating further

\footnotetext{
\$Tipton.
} 


\section{Chart 3 \\ Returns from Participating at Different Levels in the Dairy Diversion Program 1}

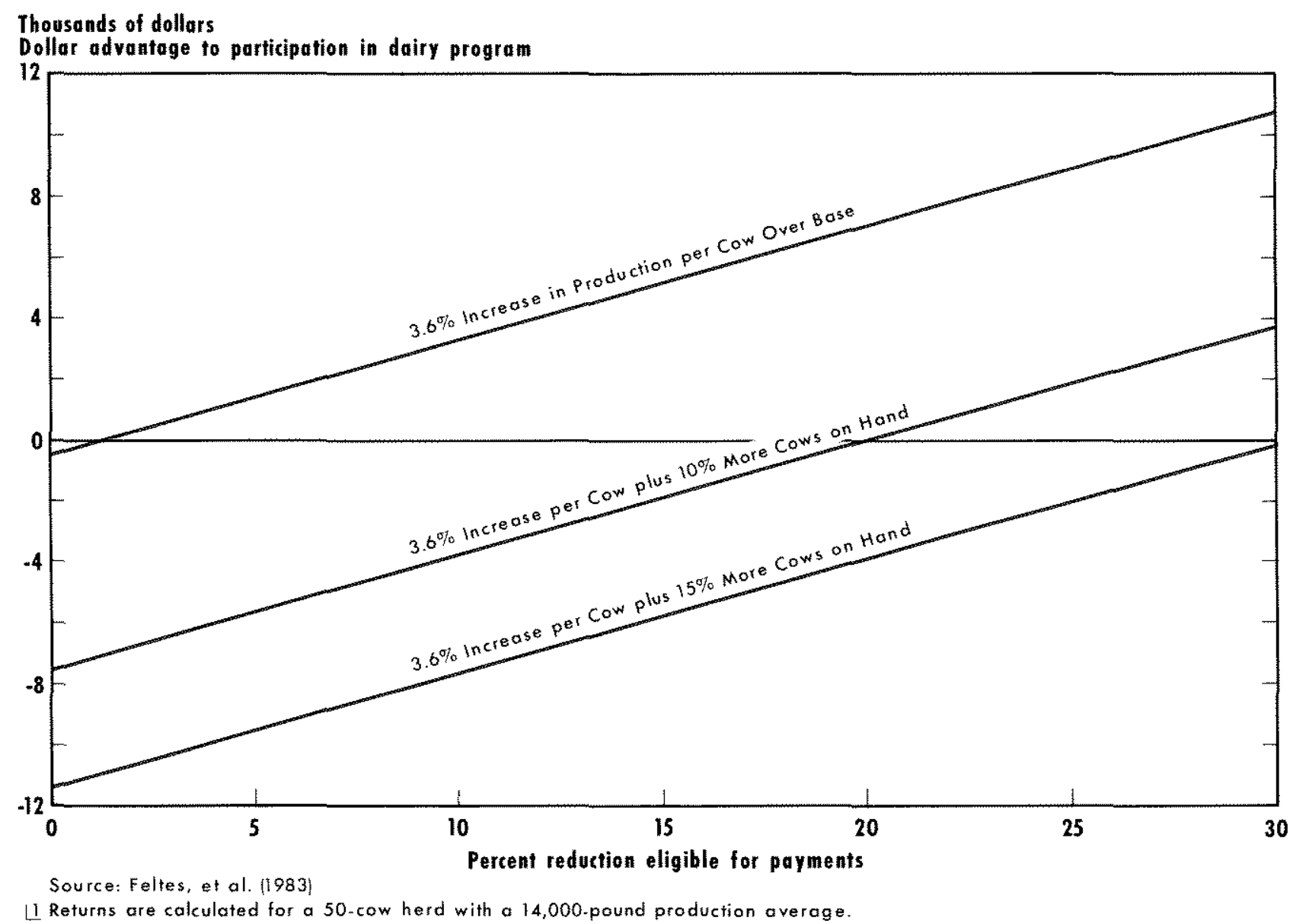

effects from projected increases in dairy product demand and revenues collected from the 50-cent fee assessment, the diversion plan was projected to have the following impacts next year:

Seven billion pounds of surplus dairy products would be produced;

The surplus product would cost $\$ 1.2$ billion to purchase and store;

The diversion payments would cost $\$ 1.5$ billion: and
O $\$ 650$ million would be collected from the 50 -cent fee assessments. ${ }^{15}$

Under these assumptions, the net cost of the dairy program in 1984 (in billions of dollars) is estimated to be:

$$
\$ 1.20+\$ 1.50-\$ .65 \simeq \$ 2.00
$$

\footnotetext{
${ }^{15}$ The proposed legistation also intends to reduce the surplus by increasing domestic demand for dairy products. This is to be achieved through increased advertising expenditures paid for with fees assessed on dairy producers. Planned expenditures of $\$ 200$ million per year for dairy advertising would be a 250 percent increase over 1982's advertising expenditures.
} 
This figure is about double the Office of Management and Budget estimates of the cost of a dairy program based solely on a reduction in the support price to $\$ 11.60 .^{16}$ The OMB also estimates that the program will increase the cost of dairy products to consumers by $\$ 1.8$ billion. ${ }^{17}$ Furthermore, the diversion payments are expected to have little effect on the long-run surplus problem because the oldest and least productive cows will be slaughtered. ${ }^{15}$ This will leave the dairy herd younger and more productive when the program and its payments end early in 1985.

\section{CONCLUSIONS}

The foregoing analysis suggests several important conclusions about the dairy price support program. First, a price support program without production controls will generate increasing surpluses and program costs. Second, the dairy price support - at least since 1980 - has been kept stbstantially above what would have otherwise been a competitive market price. This has caused an inefficient allocation of resources (too many resources allocated to dairy production) and transferred wealth from consumers and taxpayers, in general, to dairy producers and suppliers of inputs to the dairy industry. Third, efforts to reduce surplus production by paying farmers not to produce are likely to have little impact on surplus production, particularly in the long run, but will keep program costs near their current levels. Finally, the only effective way to reduce surplus dairy production is to reduce the sup-

\footnotetext{
${ }^{16}$ Jackson and Birnbaum.

${ }^{17} \mathrm{King}$ (1983b).

${ }^{19}$ More to the point, any reduction in output achieved through smaller numbers of datry cows will be short lived because output increases have come primarily from greater productivity per animal. This point is highlighted by comparing the 1.6 percent increase in the number of dairy cows between 1980 and 1983 to the 5.1 percent increase in average output per cow (from 11,889 lbs. to about 12,400 lbs. per year) over the same period.
}

port price further. Congress already has defeated a proposal to reduce the dairy price support level and has passed instead a plan to pay farmers directly for reducing output. Under these conditions, consumers can expect to pay higher prices for dairy products, while taxpayers can expect further increases in the costs of this program.

\section{PEFERENCES}

Albosta, Paul. U.S. Representative, Congressional Record, November 9, 1983, p. H9523.

Dahlgran, Roger A. "Weffare Costs and Interregional Income Transfers Due to Regulation of Dairy Markets," American Journal of Agricultural Economics (May 1980), pp. 288-96.

Donahue, John D. "The Political Economy of Milk," Atlantic Monthly (October 1983), pp. 58-68.

Feltes, Linda, et al. "The Daly Compromise Program: Who Should Participate?" FM 522, University of Minnesota Agricultural Extension Service, December 1, 1983.

Heien, Dale. "The Cost of the U.S. Dairy Price Support Program: 1949-74," Review of Economics and Statistics (February 1977), pp. $1-8$.

Ippolito, Fichard A. and Robert T. Masson. "The Social Cost of Government Regulation of Milk," Joumal of Law and Economics (April 1978), pp. 33-65.

Jackson, Brooks and Jeffrey H. Bimbaum. "Dairy Lobby Obtains U.S. Subsidies With Help From Urban Legistators," Wall Street Joumal November $18,1983$.

King, Seth S. "Dairy Bill Poses Perils For A Presidential Veto," New York Times, November 19, 1983a.

"How the Dairy Lobby Put the Squeeze on the White House," New York Times, December 4, 1983b.

Maicolm, Andrew. "Dairy Output is Still Rising Despite Laws," New York Times, November 11, 1983.

Manchester, Alden. The Public Role in the Dairy Economy (Westview Press, 1983)

Stigler, George J. The Theory of Price, 3rd ed. (The Macmillan Company, 1966).

Tangermann, Stefan. "Europe and the Road to Serfdom," The Financial Times, November 2, 1983.

Tipton, E. Linwood. "Dairy Outlook ' 84 " (paper presented at the 60th Annual USDA Outlook Conference, Washington, D.C., November $1,1983)$ 